\title{
Evaluation and Risk Analysis of Open-Pit Mining Operations
}

\author{
Alexander Pekol \\ Department Mineral Resources Engineering, Chair of Mining Engineering and Mineral Economics, \\ Montanuniversität Leoben, Leoben, Austria
}

Received March 20, 2019; accepted March 23, 2019; published online April 10, 2019

\begin{abstract}
Mining of raw materials is a process that consists of several stages. In open-pit mining, material with high compressive strength is extracted by drilling and blasting and material with low compressive strength is extracted by e.g. a bucket wheel excavator. Most important influencing factors for crusher decision are compressive strength, moisture content, capacity of crusher, abrasiveness, and feed size. Depending on sequence of mining, fixed, semifixed, semi-mobile, or fully-mobile crusher stations can be applied. Compressive strength, tensile strength, cleavage, fracture behaviour, and stickiness are the most significant influencing factors for bucket wheel excavator selection. The waste removal and dumping associated with mining must be handled very well, so that the environmental impacts are as low as possible and dump stability is guaranteed. Essential are dump foundation properties, design of dump, and construction of dump. Open-pit mining operations harbour risks which can lead to project delays, operation standstill, injury to personnel, damage to equipment, or negative impacts on the environment. Therefore, risk identification and prevention of risks is essential.
\end{abstract}

Keywords: Bucket wheel excavator, Cutting resistance, Risk analysis

\section{Beurteilung und Risikoanalyse des Tagebaubetriebs}

Zusammenfassung: Der Abbau von Rohstoffen ist ein Prozess, der aus mehreren Schritten besteht. Im Tagebau wird Material mit hoher Druckfestigkeit mittels Bohren und Sprengen und Material mit niedriger Druckfestigkeit z. B. mittels Schaufelradbagger gewonnen. Die wichtigsten Einflussfaktoren für die Entscheidung des Brechers sind Druckfestigkeit, Feuchtegehalt, Kapazität des Brechers, Abrasivität und Aufgabegröße. Abhängig von der Abbau-

\author{
A. Pekol ( $\square)$ \\ Department Mineral Resources Engineering, Chair of Mining \\ Engineering and Mineral Economics, \\ Montanuniversität Leoben, \\ Erzherzog-Johann-Str. 3, \\ Leoben, Austria \\ alexander.pekol@stud.unileoben.ac.at
}

sequenz können fixe, halb-fixe, halb-mobile oder voll-mobile Brecherstationen eingesetzt werden. Druckfestigkeit, Zugfestigkeit, Spaltbarkeit, Bruchverhalten und Klebrigkeit sind die wesentlichsten Einflussfaktoren für die Auswahl eines Schaufelradbaggers. Die mit dem Abbau verbundene Entsorgung und Verhaldung des Abraums müssen bestens gehandhabt werden, damit die Umweltauswirkungen so gering wie möglich sind und die Stabilität der Halde gewährleistet ist. Wesentlich sind die Eigenschaften der Haldenbasis, das Design der Halde und die Errichtung der Halde. Der Tagebaubetrieb birgt Risiken, die zu Projektverzögerungen, Stillstand des Betriebes, Personenschäden, Geräteschäden oder negativen Auswirkungen auf die Umwelt führen können. Daher ist die Risikoerkennung und -vermeidung von wesentlicher Bedeutung.

Schlüsselwörter: Schaufelradbagger, Schneidwiderstand, Risikoanalyse

\section{Introduction}

Open-pit mining is a very important aspect of raw materials mining and it is present all over the world. The period from the start to the construction of an open-pit mine takes several years and includes prospection/exploration, mineral extraction, and waste handling and management. Big machinery like bucket wheel excavators are used to break rock masses out of the ground that usually have low compressive strength ( $\leq 20 \mathrm{MPa}$ ) [1]. For rock masses with high compressive strength ( $>20 \mathrm{MPa})$, excavation with shovels or drilling and blasting is applied. The downstream haulage system depends on specific mine conditions (e.g. depth below surface, pushback rates, annual production) and environmental influences (e.g. emissions, surface impacts). While excavating rock mass with bucket wheel excavators, dumping is normally done by discharging the material onto a dump using conveyor systems and spreaders which run along the pit wall to the dumping area [1]. In-pit crushing and conveying (IPCC) is used to transport the blasted rock mass out of the pit by breaking it into smaller pieces with a crusher and hauling it with a conveyor belt. In com- 
Fig. 1: Sequence of IPCC operation (modified after [2])

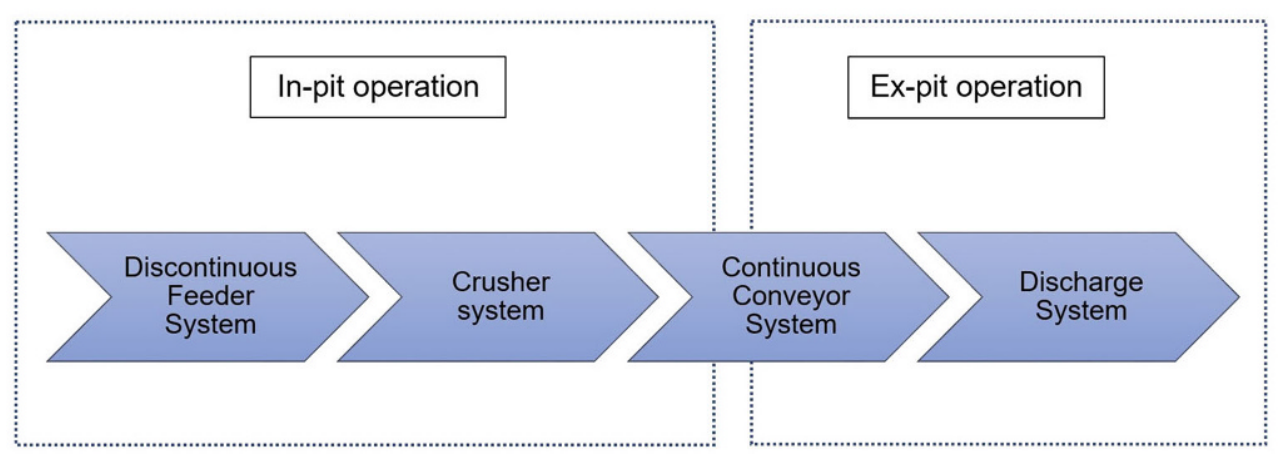

parison, haulage can be done transporting the rock mass with truck fleets. Advantages and disadvantages of both systems must be compared for several criteria to guarantee optimum choice. Open-pit mining operations harbour risks which can lead to operation standstill, injury to personnel, injury to equipment, or negative impacts on the environment.

\section{In-Pit Crushing and Conveying}

IPCC systems are haulage systems used in open-pit mines (Fig. 1) which consist of a discontinuous feed system, a crusher system, a continuous conveyor system, and a discharge system.

\subsection{Feed System}

Ritter [2] divides the feed system into cyclic excavation and cyclic intermittent haulage. Typically, excavation in IPCC systems is done by front-end loaders, hydraulic excavators, or rope shovels.

\subsection{Crusher System}

The crusher system receives material from the feed system which is excavated at the working face. In-pit crusher stations can be divided into fixed, semi-fixed, semi-mobile, and fully-mobile stations based on degree of mobility, structural design and location of operation [2]. Fixed in-pit crushers are typically gyratory or jaw crushers which are designed to operate the whole lifetime of mine at the same place [2]. Semi-mobile crusher stations are normally located at the operating bench and they can be fed by multiple loading machines (e.g. front-end loaders) [2]. Due to the agility of fully-mobile crusher stations, a simultaneous movement along the working face is possible, but only a few crushers are actually able to follow the movements of the loading unit [2]. Best application for fixed crusher systems is in deep, pre-existing pits with a low vertical advance rate. The crusher must be able to handle the operation without being relocated over a time longer than five years [3]. Fully-mobile in-pit crushing stations are best applied in greenfield operations [3].

Crusher selection depends on various parameters [2]:

- Material properties (moisture content, density, abrasiveness)

- Application requirements (product size, feed size, capacity)
Fig. 2: Crusher types related to maximum capacity and compressive strength [2]

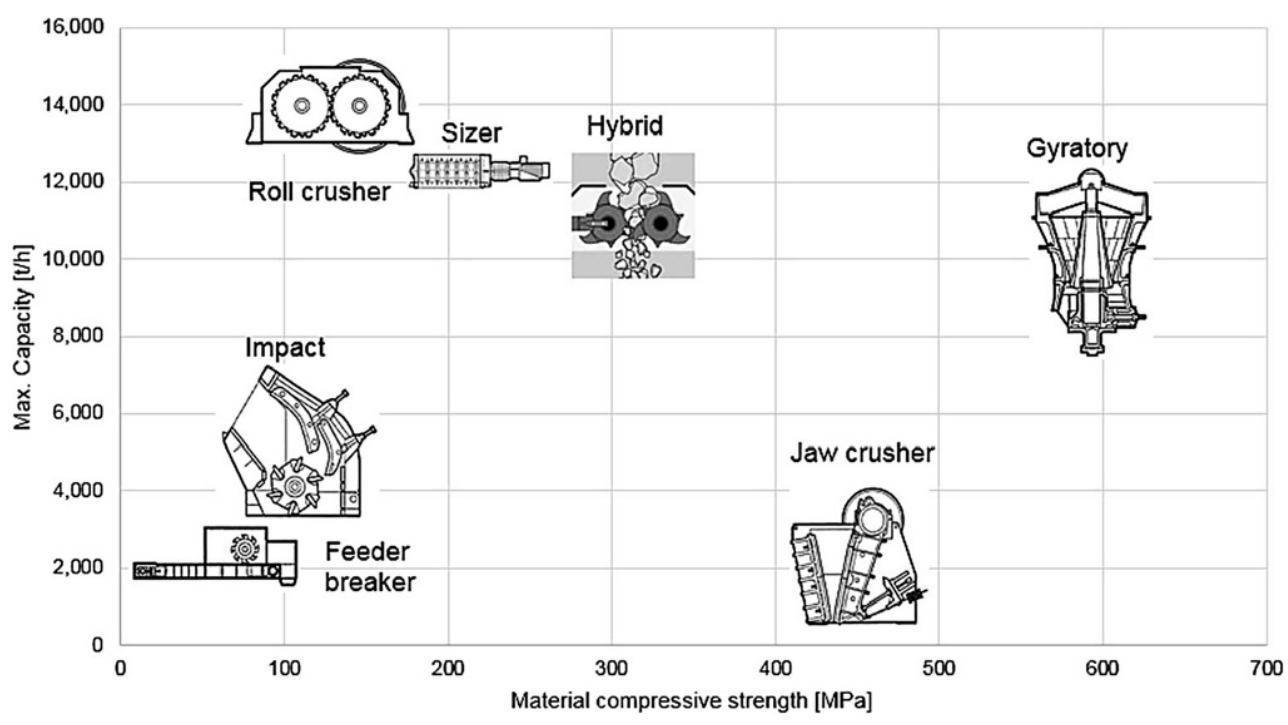




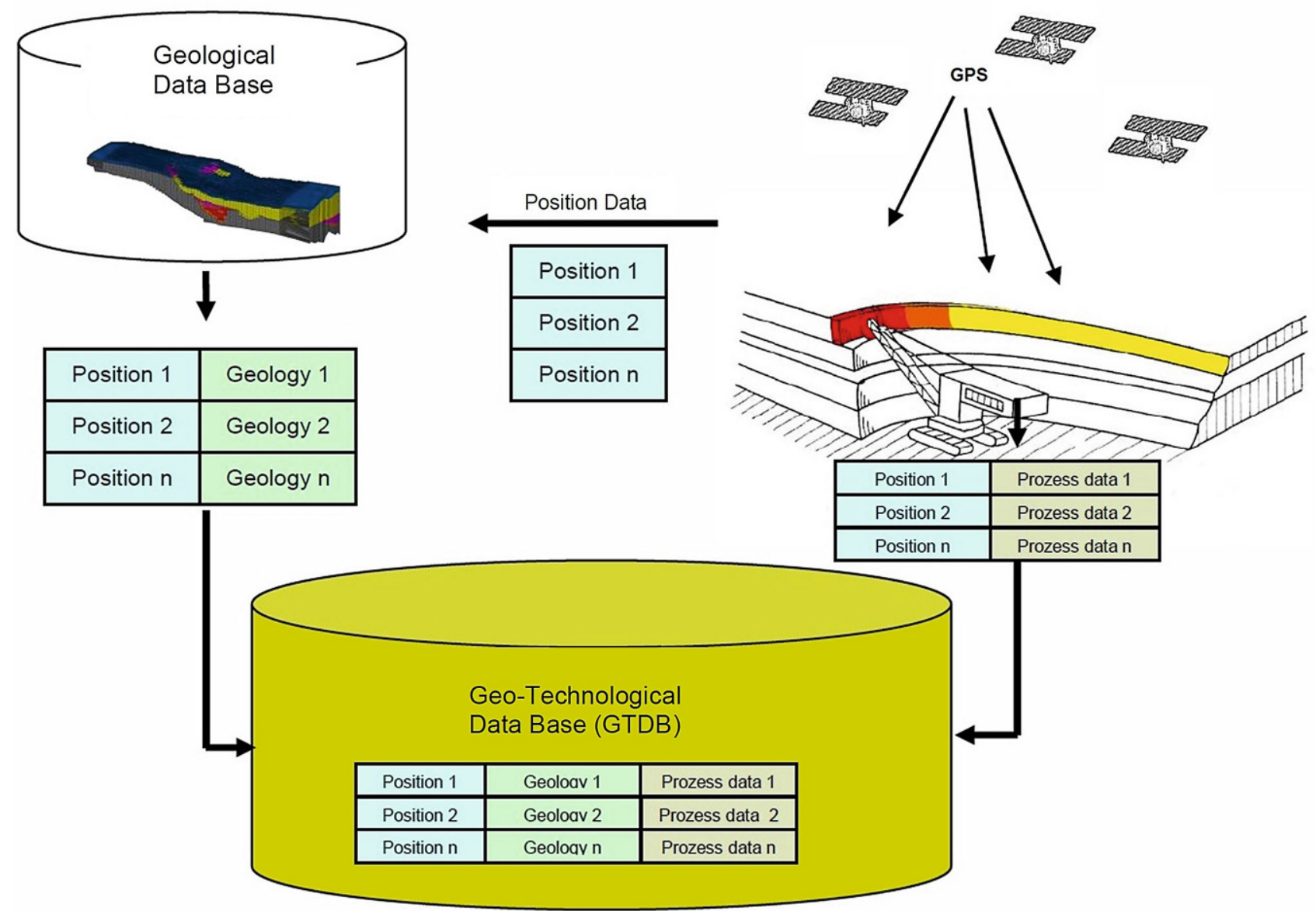

Fig. 3: Geo-Technical Data Base process [5]

Fig. 2 shows division of in-pit crushers related to maximum output and compressive strength.

\section{Bucket Wheel Excavator}

Bucket wheel excavators are used to extract material using a wheel that consists of buckets which are digging into the rock mass. Material characteristics (e.g. compressive strength, cleavage, tensile strength, fracture behaviour, stickiness) are the most important parameters that influence the design of a bucket wheel excavator [4]. Application of bucket wheel excavators is based on several investigation steps which are implemented prior to mining. For a Greenfield project, various evaluation stages are necessary. After prospection and exploration, test methods should be applied to determine uniaxial compressive strength and cutting resistance of material to get a first estimation of mine conditions. Additionally, mine conditions ought to be compared to mines with similar conditions for application of bucket wheel excavators. During operations, the documentation of process data and geological conditions is recommended. Drebenstedt [5] describes a concept developed at the University of Freiberg where process data (e.g. excavation capacity, chip parameter) and geological information are connected in a common data base. The so-called Geo-Technical Data Base (Fig. 3) connects the data and uses it for certain data analyses to improve information quality (e.g. necessary drive power in a specific geological environment).

Pre-blasting of material ensures a pre-fragmentation which is preferable for bucket wheel excavators to extract hard material. Hard interbedded inclusions/boulders have a big influence on the workability of the material that must be excavated e.g. to get access to the coal seam. Blasting of overburden or usage of other machinery (impact ripper, classic excavator) is necessary if the amount of inclusions is large [6].

\section{Waste Removal and Management}

Removal of overburden can be done via drilling and blasting or mechanical excavation to get access to the deposit. The choice depends on the properties of the material that must be excavated. While excavating overburden with bucket wheel excavators, dumping is normally done by discharging the material onto a dump using conveyor systems and spreaders which run along the pit wall to the dumping area. Spreaders are mostly mounted on crawler 


\begin{tabular}{|c|c|c|c|c|c|c|c|}
\hline Number & Stage & Risk Issue & $\begin{array}{l}\text { Risk Event/ } \\
\text { Issue }\end{array}$ & Causes & $\begin{array}{l}\text { Preventative } \\
\text { Controls }\end{array}$ & Impact & Mitigating Controls \\
\hline 6 & Operation & $\begin{array}{l}\text { Operability } \\
\text { conditions }\end{array}$ & Coal fire & $\begin{array}{l}\text { Self-ignition } \\
\text { of pyrite due } \\
\text { to oxygen } \\
\text { reaction; } \\
\text { Poor heat } \\
\text { emission } \\
\text { due to un- } \\
\text { favourable } \\
\text { fill }\end{array}$ & $\begin{array}{l}\text { Early detec- } \\
\text { tion of pyrite } \\
\text { bearing layers/ } \\
\text { formations; } \\
\text { Alternative } \\
\text { extraction/ } \\
\text { ventilation } \\
\text { method; } \\
\text { Fully extraction } \\
\text { of coal seam }\end{array}$ & $\begin{array}{l}\text { Damage to en- } \\
\text { vironment; } \\
\text { Standstill of } \\
\text { mining opera- } \\
\text { tion; } \\
\text { Injury to per- } \\
\text { sonnel }\end{array}$ & $\begin{array}{l}\text { Measurements of } \\
\text { temperature, gas } \\
\text { content; } \\
\text { Geophysical mea- } \\
\text { surements (e.g. } \\
\text { magnetic properties } \\
\text { of country rock); } \\
\text { Prevention of oxy- } \\
\text { gen supply (e.g. } \\
\text { usage of covers, bar- } \\
\text { riers); } \\
\text { Monitoring of fire } \\
\text { area }\end{array}$ \\
\hline
\end{tabular}

travel gears and they are fed by trains or conveyor systems [1]. To overcome large distances, conveyor bridges can be used additionally. If drilling and blasting have to be implemented, the material can be transported with an IPCC system out of the mine until reaching the dumping area.

Mining activities and beneficiation processes are directly related to waste generation and their disposal on Earth's surface or in mine openings. Heaps, dumps or ponds represent the impacts of these actions.

\subsection{Dump Foundation Properties}

Foundation stability and bearing capacity are assessed using shear and compressive strength characteristics [7]. Presence of fine-grained soils in foundation must be handled with care. As a result, unconfined and triaxial compression tests and direct shear tests need to be conducted on undisturbed samples, e.g. shelby tube, piston samples, block samples [7]. Mixed-grained or coarse-grained soils, softened glacial tills with a considerable amount of gravels, and cobbles/boulders are difficult to sample in an undisturbed state. In such a case, penetrometer or vane shear testing provides most reliable strength information [7]. The occurrence of discontinuities has an essential influence on stability of foundation bedrock. First estimations are done using empirical relations or simple hardness tests. Point Load Index testing of core samples would be conducted if more detailed rock strength information is required [7].

\subsection{Design and Construction of Dump}

First, selection of site for the facility must be done whereby key selection factors as regulatory and social factors, fill material quality, terrain and geology, mining, environmental factors, geotechnical components, and closure are to be considered [8].

Hawley and Cunning [8] describe procedure of dump construction as follows:

1. Initial site identification

2. Conceptual design
3. Pre-feasibility design

4. Feasibility design

5. Detailed design and construction

6. Operation

7. Closure

For initial site identification, study of regional geology plans and maps is necessary. A ranking should be applied if more than one potential site occurs. In the following step, a conceptual design (e.g. access routes, site preparation) must be implemented for each site. Capital expenditure and operational expenditure calculations with an accuracy up to $15 \%$ and laboratory and field testing have to be done in the 3 rd and 4th stage. The 5th stage consists of stability and sensitivity analysis, development of access routes, and quantitative risk assessment. Part of 6 th stage are field trials, closure plans, and ongoing monitoring of foundation. Closure includes finishing of the closure plan and implementation of plan for finished sections [8].

\section{Risk Analysis}

A risk checklist is necessary to understand open-pit mining operations and to improve safety. Several risk issues regarding environment, financial aspects, maintenance, safety, repair, availability, offer, geology, and reliability are decided to be the most important issues. A total of 99 risks were identified during literature research and brainstorming. Table 1 gives an overview of the checklist structure. For each risk, causes, preventative controls, impacts, and mitigating controls are described.

\section{Conclusion}

Selection of crusher depends on material properties, application requirements, depth of mine and pushback rates. Fixed crusher stations are located for several years at the same place whereby fully-mobile crushers are designed to follow the movement of the loading system. It must be considered that fully-mobile crushers need a larger working area than fixed crushers. 
Evaluation of bucket wheel excavator is usually based on cutting resistance and uniaxial compressive strength of rock mass. The values provided by the tests used for determination of cutting strength should be seen as reference values. It could always be helpful to compare mine conditions with conditions of other mines. During operations, process data of bucket wheel excavator and geological information of working positions must be documented. The result is an overview of lithologies and associated machinery parameters for certain exploitation positions.

Before dumping of waste piles has started, construction of a proper dump foundation is crucial. Occurrence of finegrained material and geological disturbances in the foundation must be handled with care. If the amount of fine material exceeds a certain value, it will get more difficult to dump properly. Dump construction consists of certain steps which become more and more detailed.

Mining is a sector of the industry which harbours several risks that can cause severe damage to both machinery and work force. Main reason is the huge amount of energy that is present within the system. The objective is to recognize risks in terms of operation, safety, geology, environment, finance, maintenance, repair, reliability, offer, and availability and to use preventative and mitigative controls to eliminate/reduce risks.

Funding. Open access funding provided by Montanuniversität Leoben.

Open Access This article is distributed under the terms of the Creative Commons Attribution 4.0 International License (http://creativecommons. org/licenses/by/4.0/), which permits unrestricted use, distribution, and reproduction in any medium, provided you give appropriate credit to the original author(s) and the source, provide a link to the Creative Commons license, and indicate if changes were made.

\section{References}

1. Durst, W.; Vogt, W.: Bucket wheel excavator, vol. 7, Clausthal-Zellerfeld: Trans Tech Publications, 1988

2. Ritter, R.: Contribution to the capacity determination of semi-mobile in-pit crushing and conveying systems, PhD thesis, Freiberg, TU Bergakademie, Dept. of Geosciences, Geoengineering and Mining, 2016

3. Nehring, M.; Knights, P. F.; Kizil, M. S.; Hay, E.: A comparison of strategic mine planning approaches for in-pit crushing and conveying, and truck/shovel systems, International journal of mining science and technology, 28 (2018), pp 205-214

4. Raaz, V.: Assessment of the digging force and optimum selection of the mechanical and operational parameters of bucket wheel excavators for mining of overburden, coal and partings, Braunkohle: Surface mining, 5 (1999), no. 51, pp 544-554

5. Drebenstedt, C.: State of the art and new concepts for prediction of cutting resistance on example of continuous mining equipment, in: Scientific reports on resource issues 2010, vol.1, Freiberg: IUR Office, 2010, pp 104-123 (ISBN 978-3-86012-394-2)

6. Andras, I.; Radu, S. M.; Andras, A.: Study regarding the bucketwheel excavators used in hard rock excavations, Annals of the University of Petrosani, Mechanical engineering, 18 (2016), pp 11-22

7. British Columbia Mine Dump Committee (ed.): Investigation and design of mine dumps: Interim guidelines, Victoria, B.C.: British Columbia Mine Waste Rock Pile Research Committee, 1991

8. Hawley, M.; Cunning, J. (eds.): Guidelines for mine waste dump and stockpile design, London: Taylor \& Francis, 2017

Publisher's Note. Springer Nature remains neutral with regard to jurisdictional claims in published maps and institutional affiliations. 